\title{
EPICOVID19 protocol: repeated serological surveys on SARS-CoV-2 antibodies in Brazil
}

\author{
Protocolo EPICOVID19: pesquisas sorológicas repetidas \\ de anticorpos SARS-CoV-2 no Brasil
}

Pedro Curi Hallal (https://orcid.org/0000-0003-1470-6461) ${ }^{1}$

Fernando C Barros (https://orcid.org/0000-0001-5973-1746) ${ }^{1}$

Mariângela Freitas Silveira (https://orcid.org/0000-0002-2861-7139) ${ }^{1}$

Aluísio Jardim Dornellas de Barros (https://orcid.org/0000-0002-2022-8729) ${ }^{1}$

Odir Antonio Dellagostin (https://orcid.org/0000-0003-2803-4088) ${ }^{1}$

Lúcia Campos Pellanda (https://orcid.org/0000-0002-8776-2248) ${ }^{2}$

Claudio José Struchiner (https://orcid.org/0000-0003-2114-847X) ${ }^{3}$

Marcelo Nascimento Burattini (https://orcid.org/0000-0002-5407-6890) ${ }^{4}$

Fernando Pires Hartwig (https://orcid.org/0000-0003-3729-0710) ${ }^{1}$

Ana Maria Baptista Menezes (https://orcid.org/0000-0002-2996-9427) ${ }^{1}$

Bernardo Lessa Horta (https://orcid.org/0000-0001-9843-412X) ${ }^{1}$

Cesar Gomes Victora (https://orcid.org/0000-0002-2465-2180) ${ }^{1}$

${ }^{1}$ Universidade Federal de Pelotas. Marechal

Deodoro 1160,. 96020-220

Pelotas RS Brasil.

prchallal@gmail.com

${ }^{2}$ Fundação Universidade

Federal de Ciências de

Saúde de Porto Alegre.

Porto Alegre RS Brasil.

${ }^{3}$ Universidade do Estado

do Rio de Janeiro. Rio de

Janeiro RJ Brasil.

${ }^{4}$ Universidade de São Paulo.

São Paulo SP Brasil.

\begin{abstract}
The first case of COVID-19 was reported in China in December 2019, and, as the virus has spread worldwide, the World Health Organization declared it a pandemic. Estimates on the number of COVID-19 cases do not reflect it real magnitude as testing is limited. Population based data on the proportion of the population with antibodies is relevant for planning public health policies. We aim to assess the prevalence of SARS$\mathrm{CoV}-2$ antibodies, presence of signs and symptoms of COVID-19, and adherence to isolation measures. A random sample comprising 133 sentinel cities from all states of the country will be selected. Three serological surveys, three weeks apart, will be conducted. The most populous municipality in each intermediate region of the country, defined by the Brazilian Institute of Geography and Statistics, was chosen as sentinel city. In each city, 25 census tracts will be selected, and 10 households will be systematically sampled in each tract, totaling 33,250 participants. In each household, one inhabitant will be randomly selected to be interviewed and tested for antibodies against SARSCoV-2, using WONDFO SARS-CoV-2 Antibody Test. By evaluating a representative sample of Brazilian sentinel sites, this study will provide essential information for the design of health policies. Key words COVID19, Epidemiology, Serological survey
\end{abstract}

Resumo O COVID-19 é causado pelo vírus SARS-CoV-2, sendo o primeiro caso relatado na China em dezembro de 2019. O vírus se espalhou pelo mundo, levando a Organização Mundial da Saúde a declarar uma pandemia. As estimativas do número de casos de COVID-19 não refletem sua magnitude real, pois os testes são limitados em muitos países. Dados populacionais sobre a proporção da população com anticorpos são relevantes para o planejamento de políticas públicas de saúde. Nosso objetivo é avaliar a prevalência de anticorpos SARS-CoV-2, a presença de sinais e de sintomas de COVID-19 e a adesão a medidas de isolamento. Uma amostra aleatória composta por 133 cidades sentinelas de todos os estados do país será selecionada. Serão realizados três levantamentos sorológicos, com três semanas de intervalo. Em cada cidade, serão selecionados 25 setores censitários e 10 famílias serão amostradas aleatoriamente em cada setor. Em cada domicílio, um habitante será selecionado aleatoriamente para ser entrevistado e testado para anticorpos contra SARS-CoV-2, usando o Teste de Anticorpo WONDFO SARS-CoV-2, que foi validado antes do trabalho de campo. Ao avaliar uma amostra representativa dos locais sentinela ao longo do tempo, este estudo fornecerá informações essenciais para o desenho de politicas de saúde.

Palavras-chave COVID19, Epidemiologia, Levantamento sorológico 


\section{Background}

The Coronavirus Disease 2019 (COVID-19) pandemic is evolving worldwide, and on July 13 , the number of confirmed cases in the world was around 13 million in practically all countries and territories, with more than 500,000 deaths ${ }^{1}$. In Brazil (population 209.5 million), the first COVID-19 case was notified on 23 February. By July 13 , the country had, according to official statistics, over 1,8 million confirmed cases and over 72,000 deaths $^{2}$.

These figures should be considered with caution, as available official statistics on the disease prevalence, mortality and case-fatality are subject to great uncertainty, particularly due to the absence of information on the prevalence at the population level, as well as different criteria used to consider a death as being caused by COVID-19 or not. Population-based studies are rare, and usually present low levels of infection, as in Austria $(0.33 \%)^{3}$ and Iceland $(0.6 \%)^{4}$, whereas in studies with volunteers, the prevalence tends to be higher $-2.1 \%$ in South Korea ${ }^{5}$ and $2.5 \%$ to $4.2 \%$ in Santa Clara, California ${ }^{6}$. A higher prevalence figure was observed in a small town in Germany, recently hardly hit by the infection, where the prevalence was $14 \%^{7}$. A nationwide study in Spain reported a prevalence of $5.0 \%{ }^{8}$.

Prevalence estimates obtained from convenience samples can be subject to sampling biases and their representativeness is difficult to assess. Probabilistic samples from a target population, on the other hand, can assure this representativeness and lead to more effective evidence-based public health strategies. To estimate the proportion of people with antibodies in the whole population is especially relevant for COVID-19, as it seems that many people infected with the Severe Acute Respiratory Syndrome Coronavirus 2 (SARS-CoV-2) virus present light symptoms or are even asymptomatic, even though they may transmit the disease ${ }^{9}$. Moreover, in the current situation of restrictive policies regarding social contact, knowledge about the proportion of the population with antibodies and, consequently, the number of people susceptible to get infected, will be essential to make plans for the gradual return to normal activities.

In this manuscript we present the protocol of the EPICOVID19 study, a multi-stage nationwide population-based study to estimate the prevalence and the evolution of the COVID-19 disease in Brazil. Figure 1 displays the study's logo, which represents an analogy between COVID-19 and an iceberg. The number of confirmed cases based on official statistics is analogous to the visible part of the iceberg (that is located above sea level), whereas the total number of cases at the population level is analogous to the hidden part of the iceberg, underneath the sea.

\section{Objectives}

The aims of the project are: (1) To estimate the proportion of the Brazilian population, as represented by sentinel cities, that present antibodies for SARS-CoV-2; (2) To determine the proportion of the individuals with antibodies that presented subclinical or asymptomatic infections; (3) To evaluate the most common symptoms reported by the positive subjects; (4) To analyze times trends by comparing three consecutive surveys; (5) To allow precise estimations of case-fatality rates, by using the correct proportion of infected people; (6) To evaluate adherence to isolation measures.

\section{Methods}

\section{Study setting and design}

Three population-based repeated serological surveys will be carried out in sentinel municipalities, using a protocol that was based on the World Health Organization (WHO) guidelines ${ }^{10}$. In each state, the urban area of the larger municipalities of each intermediate region defined by the Brazilian Institute of Geography and Statistics (IBGE) will be studied. The selection of sentinel municipalities is justified by the little time available and the limited availability of diagnostic tests. The three surveys will be carried out every 21 days and the first survey was carried out from May 14 to 21, the next surveys will start

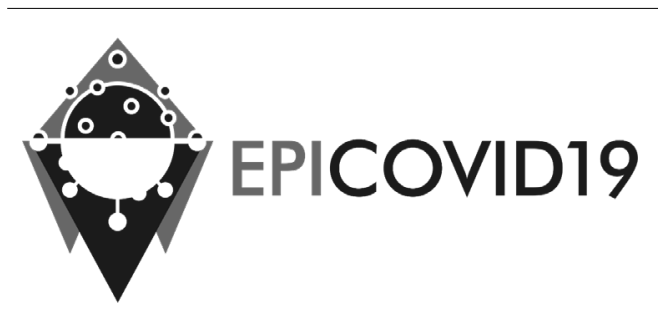

Figure 1. EPICOVID19 analogy to an iceberg study's logo. 
on June 4 and June 21 and the duration of data collection in each of these survey will be 3-5 days (Figure 2).

The sampling scheme consists of a multiple stage probabilistic sample: in each one of the 133 sentinel municipalities (from all Brazilian states - Figure 3), 25 census tracts will be selected with probability proportional to population size, respecting the order of tracts defined by IBGE (which starts in central areas and radiate to the periphery of the city and city districts). Maps of census tracts will be used to conduct a random sampling selection of a starting point for each tract. From this point, every 10th household will be systematically selected. In each sampled household, all residents will be listed and their age and sex recorded on a household member roster. One of the residents will be randomly selected for testing and interview. If the selected person refuses to participate, a second resident will be randomly selected. In case of a second refusal, the interview will be terminated, and the neighboring household will be invited to participate. All information about absences, and refusals, by the chosen resident or the household, will be registered to allow the estimation of non-response rates. In every new survey, the sampling will use the same census tracts, but different households. In each survey, 33,250 interviews will be conducted, totaling 99,750 in the full study.
The sample size, total and by municipality, was defined to balance precision of estimates and availability of tests. With the chosen sample size of 250 tests per city, we will have a precision,

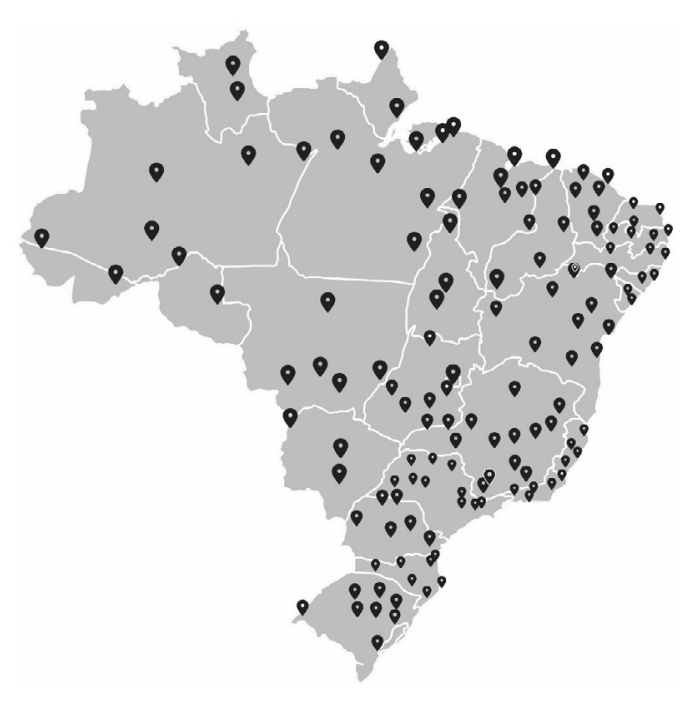

Figure 3. Location of the 133 sentinel cities included in the EPICOVID19 study.

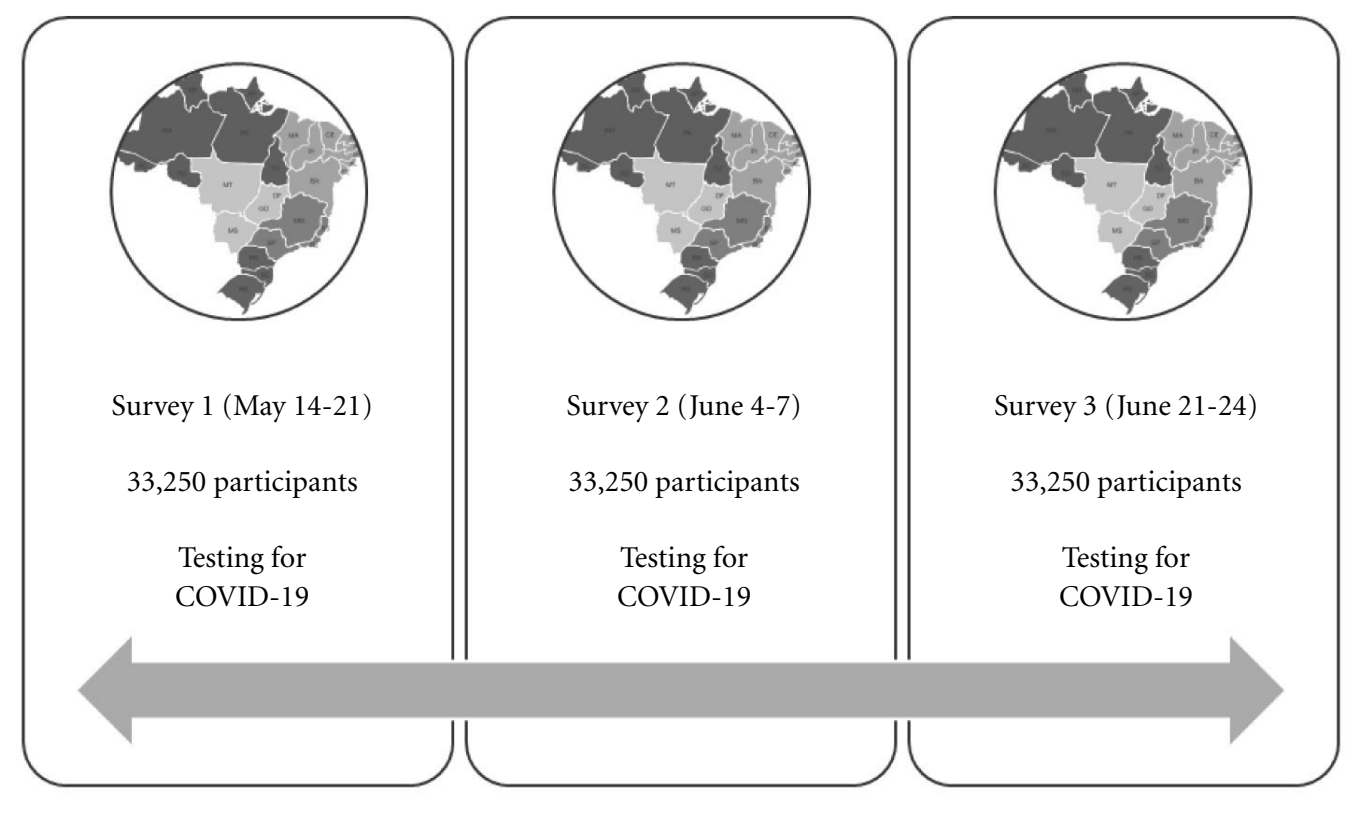

Figure 2. Timetable of fieldwork. Population-based survey on the prevalence of COVID-19 in Brazil. 
in percentage points, that varies with the prevalence: a prevalence of $1 \%$ will be estimated with a precision of 1.1 percentage points (p.p.), 5\% with a precision of 2.7 p.p., 3.8, 10\% with a precision of 3.8 p.p., $20 \%$ with a precision of 5.1 p.p., and $30 \%$ with a precision of 5.8 p.p. When estimating a prevalence for all municipalities, with a total sample size of 33,250 tests, the worst precision will be of 0.5 p.p. for a prevalence of $30 \%$.

\section{Data collection}

The detection of antibodies for SARS-CoV-2 will be made using the WONDFO SARS-CoV-2 Antibody Test, using finger prick blood samples. This test is based on the principle of immune assay of lateral flow and detect IgG/IgM antibodies against SARS-CoV-2. The validation study carried out by the manufacturer included 596 participants, and estimated a sensitivity of $86.4 \%$ and specificity of $99.6 \%$. The Brazilian National Institute for Quality Control for Health compared the test's results with Reverse Transcriptase Polymerase Chain Reaction (RT-PCR) and found a sensitivity of $100 \%$ and a specificity of $98.7 \%$ (https://en.wondfo.com.cn/product/ wondfo-sars-cov-2-antibody-test-lateral-flowmethod-2/). In our own validation (submitted for publication), $64(77.1 \%)$ tested positive out of 83 subjects with positive RT-PCR results 10 or more days after the initial diagnosis. We estimated specificity by analysing 100 sera samples collected in 2012 from participants of the 1982 Pelotas Birth Cohort Study ${ }^{11}$ and found 98 negative results. Furthermore, Whitman et al. ${ }^{12}$ evaluated 10 different lateral flow assays and reported a sensitivity of $81.5 \%$ and a specificity of $99.1 \%$ for this test. Taking all these results together, we estimate a pooled sensitivity of $84.8 \%$ (95\% CI $81.4 \% ; 87.8 \%$ ) and a pooled specificity of $99.0 \%$ (95\% CI 97.8\%;99.7\%).

Besides the SARS-CoV-2 testing, from which a photo will be taken for quality control, participants will be interviewed on demographic variables, medical conditions related to prognosis of COVID-19 (high blood pressure, diabetes, asthma, cancer, chronic kidney disease and chronic heart disease), the utilization of health care services in the same time period, and the level of adoption of the measures of social distancing (total, partial, no adoption). Interviews will be carried out using tablets and the results of tests will be photographed. Interviewers will be trained to collect the blood sample by finger prick and to conduct the antibody test.
For those who test positive, the presence of symptoms potentially related to COVID-19 (cough, fever, sore throat, difficulty breathing, palpitations, loss of taste or smell, vomiting, diarrhea, muscle pain) will be assessed. In such cases, all family members living in the same households will also be tested.

\section{Data analysis}

For estimating the proportion of the population within the 133 cities with antibodies, we will use three cumulative strategies: (a) presenting the crude estimates; (b) adjusting for the validity of the test; (c) adjusting for the clustering nature of the sample. In order to estimate the proportion of asymptomatic patients, we will estimate the proportion not reporting any of the 11 symptoms investigated. We will then estimate the most frequently reported symptoms. For analyzing times trends, we will estimate the percent change across surveys, and test for linear trend. To allow precise estimations of case-fatality rates, we will divide the number of deaths within the 133 cities by the estimated number of people with antibodies in the cities. For evaluating adherence to isolation measures, we will estimate the proportion of people reporting to stay at home all the time, to leave for essential activities only and to leave home daily.

\section{Discussion}

The EPICOVID19 study will provide local data on critical parameters of the pandemic, which can be used by decision makers to design and implement effective public health policies to mitigate the burden of COVID-19 in the country as a whole, and in each state individually. Combining all three phases of the study, this is currently the largest population-based study of SARS-CoV-2 antibodies prevalence in the world.

Reliable population-level estimates are essential for the design of effective public health policies. The present study will expand an existing study in the state of Rio Grande do Sul in Brazil $^{13}$ to the entire country. In Rio Grande do Sul, the results from the surveys already conducted demonstrated that the prevalence of SARSCoV-2 antibodies is still relatively low, possibly due to the high adherence to the population in the state to social distancing measures ${ }^{14}$. The results from this ongoing study have been essential for the formulation of the recently announced 
policy to fight COVID-19 in the state. The national study will provide the same information for the entire country, thus contributing to both state- and country-level health policy making to fight the pandemic.

\section{Collaborations}

PC Hallal had the original idea. PC Hallal, FC Barros, MF Silveira, AJD Barros, OA Dellagostin, LC Pellanda, CJ Struchiner, MN Burattini, FP Hartwig, AMB Menezes, BL Horta, CG Victora participated in the conception and design of the study, and approved the final version of the manuscript.

\section{Acknowledgements}

To IBOPE, the company responsible for data collection. This work is funded by the Brazilian Ministry of Health. The funder had no role in the design of the study and collection, analysis, and interpretation of data and in writing the manuscript. 


\section{References}

1. Johns Hopkins University. Coronavirus Resource Center. COID-19 world map, 2020. [cited 2020 Jul 10]. Available in: https://coronavirus.jhu.edu/map.html. 2020.

2. Brasil. Ministério da Saúde (MS). Conronavírus Brasil - Painel Geral, 2020. Brasília: MS; 2020.

3. Ogris G, Hofinger C (April 10, 2020). COVID-19 Prevalence (Media information), 2020. [cited 2020 Jul 10]. Available in: https://www.sora.at/uploads/ media/Austria_COVID-19_Prevalence_BMBWF_ SORA_20200410_EN_Version_fuer_HP.pdf

4. Gudbjartsson DF, Helgason A, Jonsson H, Magnusson OT, Melsted P, Norddahl GL, Saemundsdottir J, Sigurdsson A, Sulem P, Agustsdottir AB, Eiriksdottir B, Fridriksdottir R, Gardarsdottir EE, Georgsson G, Gretarsdottir OS, Gudmundsson KR, Gunnarsdottir TR, Gylfason A, Holm H, Jensson BO, Jonasdottir A, Jonsson F, Josefsdottir KS, Kristjansson T, Magnusdottir DN, le Roux L, Sigmundsdottir G, Sveinbjornsson G, Sveinsdottir KE, Sveinsdottir M, Thorarensen EA, Thorbjornsson B, Löve A, Masson G, Jonsdottir I, Möller AD, Gudnason T, Kristinsson KG, Thorsteinsdottir U, Stefansson K. Spread of SARS-CoV-2 in the Icelandic Population. N Engl J Med 2020; 328(24):2302-2315.

5. South Korea. Ministry of Health and Welfare (MHW). Coronavirus disease 19. Seul: MHW; 2020.

6. Bendavid E, Mulaney B, Sood N, Shah S, Ling E, Bromley-Dulfano R, Lai C, Weissberg Z, Saavedra -Walker R, Tedrow J, Tversky D, Bogan A, Kupiec T, Eichner D, Gupta R, Ioannidis J, Bhattacharya J. COVID-19 Antibody Seroprevalence in Santa Clara County, California. MedRxiv 2020. http://doi. org/10.1101/2020.04.14.20062463

7. Regalado A. Blood tests show $14 \%$ of people are now immune to covid-19 in one town in Germany. MIT Technology Review 2020. [cited 2020 Jul 10]. Available in: https://www.technologyreview. com/2020/04/09/999015/blood-tests-show-15-of-people-are-now-immune-to-covid-19-in-one-town-ingermany/

8. Pollán M, Pérez-Gómez B, Pastor-Barriuso R, Oteo J, Hernán MA, Pérez-Olmeda M, Sanmartín JL, Fernández-García $\mathrm{A}$, Cruz I, Larrea NF, Molina M, Rodríguez-Cabrera F, Martín M, Merino-Amador P, Paniagua JL, Muñoz-Montalvo JF, Blanco F, Yotti R, ENE-COVID Study Group. Prevalence of SARSCoV-2 in Spain (ENE-COVID):A Nationwide, Population-Based Seroepidemiological Study. Lancet 2020; S0140-6736(20)31483-31485

9. Buitrago-Garcia DC, Egli-Gany D, Counotte MJ, Hossmann S, Imeri H, Ipekci AM, Salanti G, Low N. The role of asymptomatic SARS-CoV-2 infections: rapid living systematic review and meta-analysis. Medrxiv 2020. https://www.medrxiv.org/content/10.1101/2020.04.25.20079103v2
10. World Health Organization (WHO). Population-based age-stratified seroepidemiological investigation protocol for COVID-19 virus infection. Geneva: WHO; 2020.

11. Horta BL, Gigante DP, Gonçalves H, Motta JVS, Loret De Mola C, Oliveira IO, Barros FC, Victora CG. Cohort Profile Update: The 1982 Pelotas (Brazil) Birth Cohort Study. Int J Epidemiol 2015; (2):441-441e.

12. Whitman JD, Hiatt J, Mowery CT, Shy BR, Yu R, Yamamoto TN, Rathore U, Goldgof GM, Whitty C, Woo JM, Gallman AE, Miller TE, Levine AG, Nguyen DN, Bapat SP, Balcerek J, Bylsma SA, Lyons AM, Li S, Wong AW, Gillis-Buck EM, Steinhart ZB, Lee Y, Apathy R, Lipke MJ, Smith JA, Zheng T, Boothby IC, Isaza E, Chan J, Acenas DD 2 ${ }^{\text {nd }}$, Lee J, Macrae TA, Kyaw TS, Wu D, Ng DL, Gu W, York VA, Eskandarian HA, Callaway PC, Warrier L, Moreno ME, Levan J, Torres L, Farrington LA, Loudermilk R, Koshal K, Zorn KC, Garcia-Beltran WF, Yang D, Astudillo MG, Bernstein BE, Gelfand JA, Ryan ET, Charles RC, Iafrate AJ, Lennerz JK, Miller S, Chiu CY, Stramer SL, Wilson MR, Manglik A, Ye CJ, Krogan NJ, Anderson MS, Cyster JG, Ernst JD, Wu AHB, Lynch KL, Bern C, Hsu PD, Marson A. Test performance evaluation of SARS-CoV-2 serological assays. MedRxiv 2020; 2020.04.25.20074856

13. Hallal PC, Horta BL, Barros AJD, Dellagostin OA, Hartwig FP, Pellanda LC, Struchiner CJ, Burattini MN, Silveira MF, Menezes AMB, Barros FC, Victora CG. Trends in the prevalence of COVID-19 infection in Rio Grande do Sul, Brazil: repeated serological surveys. Cien Saude Colet 2020; 25(Supl. 1):2395-2401.

14. Silveira MF, Barros AJD, Horta BL, Pellanda LC, Victora GD, Dellagostin OA, Struchiner CJ, Burattini MN, Valim ARM, Berlezi EM, Mesa JM, Ikeda MLR, Mesenburg MA, Mantesso M, Dall'Agnol MM, Bittencourt RA, Hartwig FP, Menezes AMB, Barros FC, Hallal PC, Victora CG. Population-based surveys of antibodies against SARS-CoV-2 in Southern Brazil. Nat Med 2020. https://doi.org/10.1038/s41591-0200992-3

Article submitted 10/07/2020

Approved 19/07/2020

Final version submitted 21/07/2020 